\title{
Audio-Visual Media in Learning
}

\author{
Rizal Fuady ${ }^{1 *}$, Ariffin Abdul Mutalib ${ }^{2}$
}

${ }^{\mathrm{I}}$ Graduate Program of Elementary Education, Universitas Negeri Malang, Malang, Indonesia.

${ }^{2}$ School of Multimedia Technology, and Communication, Universiti Utara Malaysia, Sintok, Kedah, Malaysia.

\begin{tabular}{|c|c|}
\hline ARTICLE INFO & A B S T R ACT \\
\hline \multirow{2}{*}{$\begin{array}{l}\text { Received: 09-03-2017 } \\
\text { Revised: 08-05-2017 } \\
\text { Accepted: 07-06-2017 } \\
\text { Keywords: } \\
\text { Media, Audio Visual, } \\
\text { Learning }\end{array}$} & $\begin{array}{l}\text { This article was created with the aim to expand the knowledge of audio-visual media } \\
\text { as a medium for channeling messages and information in learning. Well-designed } \\
\text { audio-visual learning media will help achieving learning goals. Each type of learning } \\
\text { audio visual media has characteristics, advantages and disadvantages. The use of } \\
\text { audio-visual learning media able to facilitate the learning process and optimize the } \\
\text { contents of learning materials. }\end{array}$ \\
\hline & $\begin{array}{l}\text { (c) } 2018 \text { The Authors. Journal of K6, Education, and Management (j-K6EM). ISSN: } 2580-2135 . \\
\text { Published by Graduated Program of Educational Management, Universitas Lambung } \\
\text { Mangkurat, Banjarmasin, Indonesia. This is an open access article under the open journal } \\
\text { systems } 3 \text {. }\end{array}$ \\
\hline
\end{tabular}

*Author correspondence: Rizal Fuady; E-mail: rzlfuady1@gmail.com 


\section{Introduction}

In this globalization era learning quality improvement is one of the foundations in the education improvement. Some elements that are important in use of teaching and learning process first is teaching and learning media. These two aspects are indeed interrelated in teaching and learning process. In the selection of one method or model of teaching, it will also clearly affect type of learning media that is appropriate, although there must be various other aspects that should be considered for the selection of certain learning media.

A good learning media can certainly support the learning process. Audio-visual media characteristic that has several advantages over other media such as media images, print media, and hearing media clearly become an attraction that is so strong for students. In addition, for the educators as well as the parents certainly they cannot deny how strong the effect of communication media mainly like audio-visual in student learning process at home and at school is making the learning process easier in this era. Arsyad's opinion (2003) states that, "Media learning is a tool/equipment that if it is not used properly can make learning into verbalism, misinterpretation, not centered attention, and does not give students understanding. While, if it is used properly, the learning media can make learning becomes stimulant, equate experience, and giving the same perception by all students, so the media nature to be the message channel from sender to the recipient really fulfill its function."

"Educational technology as one way of teaching that is using the technology tools, is able to be utilized optimally in the education during learning, such as: television, radio, film, overhead projector, video, computer and tape recorder. These tools in the usual teaching methodology are called props and/or audio-visual teaching tools. In educational technology these tools are called hardware and software "(Nasution, 2005). Based on technological developments, Arsyad (2005) suggests that "learning media can be grouped into 4, namely: (I) printed media, (2) audiovisual technology media, (3) computer technology-based media, (4) printed and computer combined media
". Audio visual media is the easiest to use and understand by the students from various media. "

The use of audio-visual media that is easily understood by students then facilitates the process of teaching and learning, it also can motivate children to understand the subject matter. According to Hardjito (2004) "Audiovisual media is used as a medium that is presenting concrete experience through visualization with the aim of introducing, clarifying the abstract concepts, and encouraging the emergence of further learning activities. Consequently, it is conducted by the visualization of abstract concept to be more concrete. "So, the audio-visual media facilitates understanding of students in the process of learning to understand something abstract into something concrete.

Audio-visual media itself is a combination of audio and visual or can be called the view and hearing media (Hamdani, 20II). With the presence of audio-visual media, it makes the teaching materials content to students becomes easier, complete, and optimal. In addition, audio visual media can replace teacher role and duties in presenting the learning materials. Teachers are one of the critical success factors in school learning. According to Haryoko (2009) "role of today's teacher is no longer as a learning center (teacher center). Further, along with the change of learning paradigm where students are required to be more active in learning (student center) the teacher only gives a role as a facilitator, which is to provide easiness for students to learn. "

Consequently, by this state the educators are expected to prefer using audio visual media in facilitating explanation the learning materials in school. This is reinforced by Pribadi's opinion (2004) which is revealing that "audiovisual media is widely used to teach a learning experience that cannot be seen directly, this is because audiovisual media have the potential to show parts of an object realistically." As a facilitator, teachers are expected to be creative and innovative in using and creating learning media. In line with Arsyad (2005), "teacher is required to be able to use the tools provided by the school, and it is possible that the tools are in accordance with the time development and demand." Audio-visual materials can provide many benefits if teachers play an active role in learning process. 


\section{Results and Discussion}

\section{I The Media Definition}

According to Arsyad (2003), The word of media comes from Latin and this is a plural word of medium meaning intermediary or introduction. Media is an intermediary or messages sender from sender to the recipient. Meanwhile, Basyiruddin (2002) argues that "Media is any physical tool can present the message and stimulate the students to learn. Media should be manipulate-able, viewable, heard-able and readable. Further, any limitations given to it, there is always equality between these limits: the media is anything that is capable of transmitting messages from sender to receiver so that it can stimulate students' thoughts, feeling, attention, and interest in such a way that the learning process takes place and the learning objectives are achieved (Sadiman, 2010). Therefore, media is an intermediary message used in presenting something to be easily understood by the message recipient. Starting from the abstract and manipulated into something concrete.

According to Satiadarma (2006) based on technological developments, the media can be grouped into (I) Printed media. Printing technology is a way of generating or delivering material, such as books and static visual materials primarily through mechanical or photographic printing processes. Media groups resulting from printing technology includes text, graphics, photos or photographic and reproduction representation; (2) Audio-visual media. Audio-visual technology is how to produce or deliver materials using mechanical and electronical machines in order to present audio and visual messages; (3) Computerbased media. Computer-based media is a path that is generating or delivering materials using microprocessor-based sources.

Media are medium for channeling the learning information or message channeling. Therefore, according to Haryoko (2009), educational media are integral part of the education process, and this is one aspect that should be mastered by every teacher in conducting its professional function." In addition, because in this field has evolved a change in public attitudes with the science and technology progress, the field is interpreted more broadly and has a broader function, so it has a very important value in education.

\subsection{Audio Visual Media}

It is a medium involving the sense of hearing and sight in one process. According to Djamarah (2010), Audio-visual media is the medium having the elements of sound and images. This media has a better ability than others, because it covers both media namely audio media and visual media. Raharja (2000) suggests that audio-visual media are modern instructional medium fits with the era development (science progress, and technology include visible and audible media).

According to Setiadarma (2006), audio visual learning media are audio visual technology on how to produce or deliver material by using mechanical and electronic machines for audio and visual messages. The audio-visual media main features are linear, present a dynamic visualization, it is used in a predetermined manner by its designer/ manufacturer, it is a physical representation of real ideas or abstract ideas, it is developed according to psychological principles of behaviorism and cognition, and it is oriented to teachers with low levels of student interactive engagement.

From Haryoko's Opinion (2009), the effectiveness of conceptually learning can be interpreted as a treatment in learning process having the characteristics an atmosphere that can give an effect, or something memorable to the appearance; and success of the business or actions affecting student learning result.

In addition, the effectiveness of learning through visual media can be seen from the student/college student enjoyment when learning (reading) text that is pictorial or moving. Pictures, symbols or visual symbols can inspire students' emotion and attitude. According to Hamalik (I989), learning media in learning process can generate new desire and interests, to be able to generate motivation and stimulation of learning activities, and brings psychological effect on students. The use of instructional media will greatly help the effectiveness of learning process and message delivery as well as content of the lessons, in accordance with the curriculum demands. 


\subsection{Audio Visual Media Types}

\section{Sound and Motion Film}

Film media can be classified as the audio-visual media capable of showing moving and vocal film. This film media has been widely used for entertainment purposes to the field of education and learning. This medium can reveal a event object like the real state.

\section{Video}

The word video comes from Latin language, videovidi-visum meaning to see (have a vision). Meanwhile, KBBI interprets "the video by: I) the part that is emitting images on a television set, 2) the image-recording live for broadcast on television." It can be concluded that video is a telecommunication tool that can be seen by the five senses (eyes), which is a live image (motion). In addition, video is including audiovisual media which are divided into two types. First type, it is equipped with sound and image equipment in a single unit, called pure audio-visual media, such as motion film (movie) sound, television, and video. Second type, it is impure audio-visual media, namely what we known as slide, opaque, overhead projector and visual equipment.

\section{Television}

"Television is electronic equipment which is basically the same with live image includes image and sound. Television is the same as film, it can be seen and heard. Usually, the form of television is in rectangular or cube-shaped with an increasingly diverse size and model which can display images and sound at once, so it is no wonder that TV can also be used as a learning medium (Hamalik, I989: 134). "Yet television is not said as a medium of learning if it does not contain certain information or teaching materials to be delivered. There are exceptions, for example, using television as a visual aid to explain about the components existed in television and how it works, and then the used television can function as a medium of learning (Susilana \& Riyana, 2009). Then the television is important in the learning device.

\section{Conclussion and Recomendations}

There are several types of Audio-Visual learning media, namely (I) Motion and Sound Film. Film media can be classified as audio-visual media that can present moving film. This film media has been widely used for entertainment purposes, to the field of education and learning. This Media can reveal the event object as the real situation or real (2) Video. Video is a telecommunication device that can be seen by the senses (eye), in the form of live images (motion); (3) Television. Television is an electronic equipment that is essentially the same as a live picture including pictures and sound. Television is the same as film, it can be seen and heard. Usually, the form of television is in rectangular or cube-shaped with an increasingly diverse size and model which can display images and sound at once, so it is no wonder then that TV can also be used as a learning medium.

\section{Acknowledgment}

No acknowledgment

\section{References}

Arsyad, A. (2003). Media pembelajaran. Jakarta: Raja Grafindo Persada.

Arsyad, A. (2005). Media pembelajaran. Jakarta: Raja Grafindo Persada.

Arsyad, A. (2007). Media pembelajaran. Jakarta: Raja Grafindo Persada.

Asyar, R. (2012). Kreatif mengembangkan media pembelajaran. Jakarta: GP Press.

Basyiruddin, U. (2002). Media pembelajaran. Jakarta: Ciputat Pers.

Djamarah, S.B. (2010). Strategi belajar mengajar. Jakarta: Rineka Cipta

Hamalik, O. (I989). Media pembelajaran. Bandung: Citra Aditya Bakti.

Hamdani. (20II). Strategi belajar mengajar. Bandung: Pustaka Setia.

Hardjito. (2004). Peran guru dalam pemanfaatan media pembelajaran ditinjau dari perspektif progresif. Teknodik, 7(I4), 85-I07,

Haryoko, S. (2009). Efektivitas pemanfaatan media audio-visual sebagai alternatif optimalisasi model pembelajaran. Jurnal Edukasi. 5(I), I-IO.

Nasution. (2005). Teknologi pendidikan. Jakarta: Bumi Aksara.

Pribadi, B.A. (2004). Ketersediaan dan pemanfaatan media dan teknologi pembelajaran di perguruan tinggi. Jurnal Pendidikan. 5(2), I45-I56. 


\section{ISSN 2580-2135}

Raharja. (2000). Media pendidikan. Jakarta: Raja Wali. Setiadarma, W. (2006). Produksi media pembelajaran. Surabaya: Unesa University Press.

Susilana, R., \& Riyana, C. (2009). Media pembelajaran: hakikat, pengembangan, pemanfaatan, dan penilaian. Bandung: Wacana Prima. 
ISSN 2580-2135 